\title{
THE EFFECT OF FERTILIZATION ON TIME DOMAIN REFLECTOMETRY PROBE MEASUREMENT ACCURACY IN THE FIELD EXPERIMENT IN SLOVAKIA
}

\author{
Lucia TOKOVÁ, Dušan IGAZ*, Elena AYDIN, Ján ČIMO, Ján HORÁK \\ Slovak University of Agriculture in Nitra, Slovakia
}

\begin{abstract}
The paper presents evaluation of the calibration method using side-by-side direct gravimetric and indirect time domain reflectometry (TDR) for soil moisture measurements to improve TDR measurement accuracy. Measurements were carried out at the experimental site Dolná Malanta (Slovakia) in 2017. Two non-fertilized treatments - without biochar (B0 + N0) and with biochar at $20 \mathrm{t} \cdot \mathrm{ha} \mathrm{a}^{-1}(\mathrm{~B} 20+\mathrm{N} 0)$ - and two fertilized treatments - with biochar at $20 \mathrm{t} \cdot \mathrm{ha}^{-1}$ and $\mathrm{N}$ fertilizer at dosages of $160 \mathrm{~kg} \cdot \mathrm{ha}{ }^{-1}$ (B20 $\left.+\mathrm{N} 160\right)$ and $240 \mathrm{~kg} \cdot \mathrm{ha}^{-1}(\mathrm{~B} 20+\mathrm{N} 240)$ - were used in this study. The study also investigates the relationship between both used methods of soil water content determination. A strong correlation between both methods was observed. In case of (B0 + N0); (B20 + N0); $(\mathrm{B} 20+\mathrm{N} 160) ;$ and $(\mathrm{B} 20+\mathrm{N} 240)$, it was $0.93 ; 0.97 ; 0.97 ;$ and 0.98, respectively. However, it is assumed that the TDR probe may show errors in the results without prior calibration. It was observed that the accuracy of TDR device was lower for fertilized treatments in contrast to the gravimetric method and non-fertilized treatments. It is assumed that the higher measurement inaccuracy might be increased by salt concentration in the soil as a result of applied $\mathrm{N}$ fertilizer.
\end{abstract}

Keywords: soil moisture; fertilizer; time domain reflectometry; gravimetric method

Accurate measurement of soil moisture is essential for many investigations in agriculture, horticulture, ecology, forestry, hydrology, civil engineering, waste management and other environmental fields (Smith and Mullins, 2001; Chandler et al., 2014; Susha et al., 2014; Shaikh et al., 2019; AbbaspourGilandeh et al., 2018). Methods used for determination of the soil moisture content are divided into direct gravimetric methods, relying on the principle of determining the amount of water in the soil, and the indirect methods, relying on the principle of measuring the specific soil property which is dependent on soil moisture (Quinones and Nemeth, 2003; Antal and Igaz, 2012). Gravimetric method can be performed on both disturbed and undisturbed soil samples and it is not affected by the soil type and salinity and is easily computable. It is the standard reference method, on the basis of which the other techniques are usually calibrated. However, this method has also certain disadvantages. It is rather timeconsuming in terms of soil sampling and subsequent drying in the oven until the constant weight is reached and it does not allow repetition of the measurement at the same site. Furthermore, the topsoil is severely disrupted during the soil sampling, indicating destructive aspects (Susha et al., 2014; Antal et al., 2014; Tanriverdi et al., 2016). On the contrary, indirect soil water content determination using probes is much faster than soil sampling for gravimetric method (Shukla et al., 2014). The most commonly used indirect methods of soil moisture measurement in the soil hydrology include: tensiometric method, electrical methods, dielectric methods and neutron probe method (Antal et al.,
2014). The most common dielectric method used is time domain reflectometry (TDR) method. TDR is nowadays well-established method that determines the soil moisture content using the frequency in the range from $10 \mathrm{MH}_{\mathrm{z}}$ to $12 \mathrm{GH}_{\mathrm{z}}$. Application of TDR principles for determination of soil moisture has been widely accepted as an alternative method proposing an empirical relationship between the dielectric constant of soil and soil water content (Smith and Mullins, 2001; Quinones and Nemeth, 2003). Considering the saline soils, in certain cases, the imaginary part of the dielectric constant can also affect the TDR reading. When the electrical conductivity of the pore water is higher than 8-10 dS $\cdot \mathrm{m}^{-1}$, the TDR overestimates volumetric water content. In such a manner, TDR values can be bias-free, and simultaneously underestimated, overestimated, or both underestimated and overestimated in relation to values determined by the gravimetric method. The influence of high electrical conductivity on TDR measurements seems to be soil specific (Bonnell et al., 1991; Wyseure et al., 1997; Hook et al., 2004).

The nitrogen fertilization affects the soil chemical properties, which can be followed by the lower accuracy of TDR measurements. Therefore, the aim of this study was to analyse the impacts of fertilization by inorganic nitrogen (N) at doses of 160 and $240 \mathrm{~kg} \cdot \mathrm{ha}^{-1}$ on soil moisture content measurement using HydroSense II probe on the basis of the TDR method. 


\section{Material and methods}

\section{Experimental site}

Field experiment was established on March 2014 at the experimental site of the Slovak University of Agriculture in Nitra located in Dolná Malanta $\left(48^{\circ} 19^{\prime} 00^{\prime \prime} \mathrm{N} ; 18^{\circ} 09^{\prime} 00^{\prime \prime}\right.$ $\mathrm{E})$ in the Nitra region of Slovakia. The experimental site was used for agricultural production and research purposes in order to examine the effect of biochar application at different application doses on greenhouse gas emissions, soil chemical and physical properties and crop yields (Horák et al., 2017; Kondrlová et al., 2017; Vitková et al., 2017; Kondrlová et al., 2018; Igaz et al., 2018; Juriga et al., 2018; Šimanský et al., 2018). The biochar used for the experiment was produced from the mixture of paper fibre sludge and cereal husks using pyrolysis process at $550{ }^{\circ} \mathrm{C}$ for $30 \mathrm{~min}$ in a Pyreg reactor (Pyreg GmbH, Dörhe, Germany) and applied at doses of 0,10 and $20 \mathrm{t} \cdot \mathrm{ha}^{-1}$ to trial plots and incorporated into the top layer of soil $(0-10 \mathrm{~cm})$ in 2014 . The $N$ fertilizer was manually applied twice (May $9^{\text {th }}$ and August $14^{\text {th }}$ ) during 2017 at doses of 160 and $240 \mathrm{~kg} \cdot \mathrm{ha}^{-1}$ in the form of calcium ammonium nitrate. The lower applied rate of $\mathrm{N}$ was calculated according to the requirements of each crop using the balance method; the higher rate of $\mathrm{N}$ included $50 \%$ more $\mathrm{N}$-fertilizers than the lower rate of $\mathrm{N}$. The soil is classified as Haplic Luvisol according to the Soil Taxonomy (IUSS Working Group WRB, 2014) with $9.13 \mathrm{~g} \cdot \mathrm{kg}^{-1}$ of soil organic carbon, $5.71 \mathrm{pH}$ and silty loam texture (content of sand $15.2 \%$, silt $59.9 \%$ and clay $24.9 \%$ ). The area is characterized by warm lowland climate with long, warm and dry summers, short, dry winters and only a very short duration of snow cover (Igaz et al., 2018). The mean annual air temperature at the Dolná Malanta site in 2017 was $7.9^{\circ} \mathrm{C}$ and the annual rainfall was $489 \mathrm{~mm}$.

\section{Soil moisture measurement}

Soil moisture measurements were conducted during the corn growing season (GS) in 2017. The measurements by means of both gravimetric and TDR methods were conducted at the following treatments: $\mathrm{BO}+\mathrm{NO}-$ control treatment (biochar $0 \mathrm{t} \cdot \mathrm{ha}^{-1}$, nitrogen $0 \mathrm{~kg} \cdot \mathrm{ha}^{-1}$ ), B20 + N0 (biochar $20 \mathrm{t} \cdot \mathrm{ha}$ ${ }^{1}$, nitrogen $0 \mathrm{~kg} \cdot \mathrm{ha}^{-1}$ ), B20 + N160 (biochar $20 \mathrm{t} \cdot \mathrm{ha}^{-1}$, nitrogen $160 \mathrm{~kg} \cdot \mathrm{ha}^{-1}$ ) and B20 + N240 (biochar $20 \mathrm{t} \cdot \mathrm{ha}^{-1}$, nitrogen 240 $\left.\mathrm{kg} \cdot \mathrm{ha}^{-1}\right)$. The volumetric water content (VWC) measurements were conducted weekly from April to May and on monthly basis during the rest of the corn GS (June to October 2017). Undisturbed soil samples were taken from the topsoil $(10 \mathrm{~cm}$ depth) with a special coring tool with a fixed volume of 100 $\mathrm{cm}^{3}$. Soil sampling was performed at 3 randomly selected locations at plots representing each of 4 treatments for VWC determination. Volumetric water content in the soil samples was calculated as follows:

$$
V W C=\frac{V_{w}}{V_{t}}
$$

where:

$V_{w}$ - volume of soil water phase $\left(\mathrm{cm}^{3}\right) ; V_{t}$ - total volume of the soil sample $\left(\mathrm{cm}^{3}\right.$ ) (Antal and Igaz, 2012; Shukla et al., 2014; Lima et al., 2018)
Simultaneously, TDR equipment was used for the purposes of performing the measurements at the same time and location of soil sampling. The TDR measurements were performed using HydroSense II system - model CS659 (Campbell Scientific, Inc. ${ }^{\circledR}$ ). It uses a proprietary technique to determine the water content in widely varying soils with corrections for a range of bulk electrical conductivities. A display (sensor with two $12 \mathrm{~cm}$ long rods) and processing software belong to the major system components. The HS2 presentsmeasuredVWCasvolumetric watercontent (\% vol.). In order to achieve the accurate repeatable measurements, the sensor rods must be fully inserted into the soil during the measurement. If the water content over a large area is to be determined, several measurements may be required to establish a representative measurement. The calibration coefficients used by the HS2 were determined for typical soil types under laboratory conditions by the manufacturer. The device accuracy is $\pm 3 \%$ VWC for typical mineral soils with solution electric conductivity $\leq 6.5 \mathrm{dS} \cdot \mathrm{m}^{-1}$. When measuring atypical soils, user-determined coefficients can be applied. Soil-specific calibration can be performed using an independent measurement of water content such as by gravimetric analysis (Product Manual HS2 and HSP2, 2019).

\section{Results and discussion}

The calibration of TDR probes is sensitive to variations in soil properties, such as soil texture. Gravimetric method is a standard method that can be applied to calibration of all indirect methods (Chandler et al., 2014; Tanriverdi et al., 2016). Shukla et al. (2014) as well as Holzman et al. (2017) by comparison of values obtained by standard gravimetric method with values measured by soil moisture sensors calculated linear regression equations for each soil type. The field comparison of gravimetric and TDR water content measurements gives a good confidence in the TDR calibration relationships. In the research of Tanriverdi et al. (2016), TDR calibration was found to fit the gravimetrically determined volumetric water content data very well (with $R^{2}=0.995$ ). In the case presented, the CS659 sensor used was calibrated for 4 different treatments: $\mathrm{B} 0+\mathrm{N} 0 ; \mathrm{B} 20+\mathrm{N} 0 ; \mathrm{B} 20+\mathrm{N} 160$; and $\mathrm{B} 20+\mathrm{N} 240$. The mean soil volumetric water content values determined by drying of soil samples and measured by the TDR in the field are provided in Table 1.

The regression relationship between gravimetric and TDR methods expressed by calibration equations is shown in Fig. 1. These equations were used to recalculate (calibrate) values of soil volumetric water content determined by TDR method, which are also listed in Table 1 (as a mean).

The Pearson correlation coefficient showed a very high correlation between TDR and gravimetric method. The determined correlation coefficients $\left(R^{2}\right)$ for $\mathrm{B} 0+\mathrm{N} 0 ; \mathrm{B} 20+\mathrm{N} 0$; $\mathrm{B} 20+\mathrm{N} 160 ;$ and B20 + N240 were 0.93; 0.97; 0.97; and 0.98, respectively. Table 2 presents a comparison of the number of measured and calibrated values to the total number of measurements that are within $\pm 10 \%$ threshold of the values obtained utilizing gravimetric method (Igaz et al., 2008). Before TDR device calibration, only $67 \%$ of all measured values were within $\pm 10 \%$ threshold when compared to 
Table 1 Measured values of VWC (\%) by the gravimetric and TDR methods and calibrated TDR values

\begin{tabular}{|c|c|c|c|c|c|c|c|c|c|c|c|c|c|c|c|}
\hline & & \multicolumn{4}{|c|}{ 홀 } & \multicolumn{5}{|c|}{$\sum^{\frac{\pi}{2}}$} & \multirow{2}{*}{$\begin{array}{l}\stackrel{0}{\Xi} \\
29\end{array}$} & \multirow{2}{*}{$\begin{array}{l}\frac{\lambda}{5} \\
18\end{array}$} & \multirow{2}{*}{ 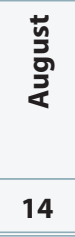 } & \multirow{2}{*}{ 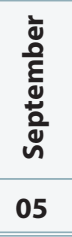 } & \multirow{2}{*}{ 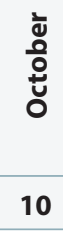 } \\
\hline & & 03 & 10 & 21 & 24 & 03 & 09 & 15 & 22 & 29 & & & & & \\
\hline \multirow{3}{*}{$\begin{array}{l}\text { 을 } \\
+ \\
\text { ○ }\end{array}$} & $\begin{array}{l}\text { measured values } \\
\text { (gravimetric) }\end{array}$ & 28.2 & 30.2 & 29.1 & 29.3 & 30.8 & 29.9 & 30.2 & 28.1 & 26.7 & 19.5 & 20.8 & 15.1 & 14.7 & 29.2 \\
\hline & measured values (TDR) & 28.8 & 29.6 & 28.3 & 28.6 & 33.3 & 32.0 & 32.6 & 30.4 & 28.3 & 16.4 & 19.6 & 13.4 & 17.2 & 29.3 \\
\hline & calibrated values (TDR) & 27.9 & 28.6 & 27.5 & 27.8 & 31.8 & 30.7 & 31.2 & 29.3 & 27.5 & 17.6 & 20.3 & 15.0 & 15.0 & 28.4 \\
\hline \multirow{3}{*}{$\begin{array}{l}\text { ㅇ } \\
\text { + } \\
+ \\
\text { 尺 } \\
\text { ஸे }\end{array}$} & $\begin{array}{l}\text { measured values } \\
\text { (gravimetric) }\end{array}$ & 28.6 & 28.5 & 28.4 & 29.7 & 30.9 & 30.0 & 27.7 & 23.5 & 21.5 & 17.0 & 21.4 & 15.2 & 12.9 & 28.3 \\
\hline & measured values (TDR) & 28.3 & 28.9 & 30.3 & 30.2 & 32.0 & 32.2 & 30.5 & 24.5 & 23.4 & 16.0 & 19.0 & 13.9 & 10.9 & 28.9 \\
\hline & calibrated values (TDR) & 27.3 & 27.8 & 28.9 & 28.9 & 30.4 & 30.5 & 29.2 & 24.2 & 23.3 & 17.2 & 19.7 & 15.4 & 13.0 & 27.8 \\
\hline \multirow{3}{*}{$\begin{array}{l}8 \\
\frac{8}{z} \\
+ \\
\stackrel{N}{0}\end{array}$} & $\begin{array}{l}\text { measured values } \\
\text { (gravimetric) }\end{array}$ & 27.7 & 29.4 & 27.8 & 29.2 & 30.9 & 29.4 & 28.4 & 24.1 & 25.8 & 17.2 & 21.9 & 17.7 & 15.6 & 27.3 \\
\hline & measured values (TDR) & 27.6 & 29.2 & 28.9 & 28.7 & 31.7 & 31.4 & 30.5 & 25.8 & 23.7 & 14.7 & 18.9 & 14.4 & 12.9 & 26.8 \\
\hline & calibrated values (TDR) & 27.4 & 28.6 & 28.4 & 28.2 & 30.5 & 30.3 & 29.6 & 26.0 & 24.5 & 17.7 & 20.8 & 17.4 & 16.3 & 26.8 \\
\hline \multirow{3}{*}{$\begin{array}{l}\text { O } \\
\text { N } \\
\text { ż } \\
+ \\
\text { ্ָ }\end{array}$} & $\begin{array}{l}\text { measured values } \\
\text { (gravimetric) }\end{array}$ & 27.7 & 29.9 & 28.6 & 28.4 & 30.8 & 30.5 & 29.4 & 28.4 & 26.5 & 20.0 & 21.1 & 17.3 & 17.0 & 28.3 \\
\hline & measured values (TDR) & 28.1 & 28.5 & 27.2 & 28.0 & 31.4 & 32.0 & 28.9 & 27.9 & 23.8 & 16.4 & 18.1 & 13.1 & 15.0 & 27.1 \\
\hline & calibrated values (TDR) & 28.6 & 28.9 & 27.9 & 28.5 & 31.2 & 31.6 & 29.2 & 28.5 & 25.3 & 19.6 & 20.9 & 17.1 & 18.5 & 27.9 \\
\hline
\end{tabular}
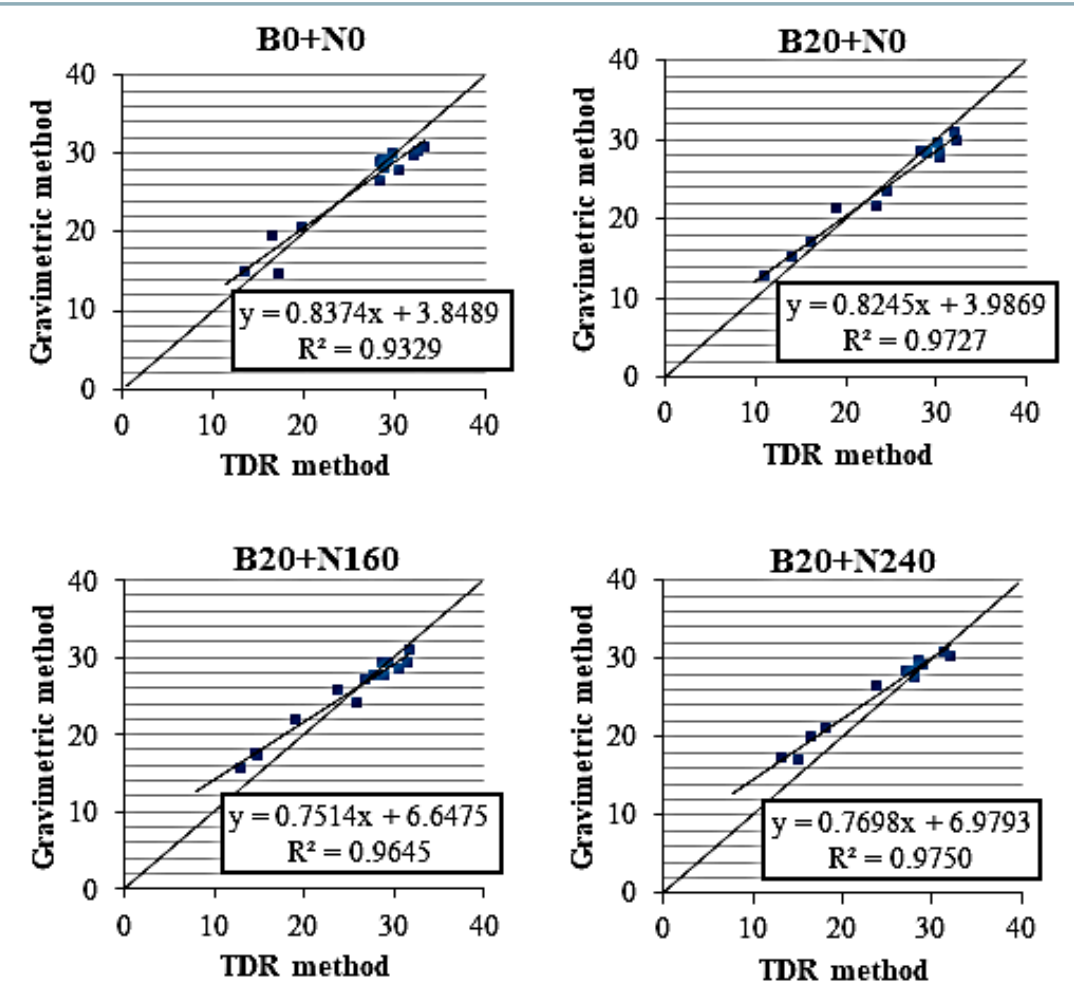

Fig. 1 Linear relationship between gravimetric and TDR methods and calibration equations gravimetric method used for $\mathrm{BO}+$ $\mathrm{N} 0, \mathrm{~B} 20+\mathrm{N} 0$ and $\mathrm{B} 20+\mathrm{N} 160$. In case of B20 + N240, it was only $62 \%$. After calibration, this amount increased for all four treatments to $81 \% ; 86 \% ; 83 \%$; and $81 \%$ for $\mathrm{B} 0+\mathrm{N} 0, \mathrm{~B} 20+\mathrm{N} 0, \mathrm{~B} 20+$ $\mathrm{N} 160$ and $\mathrm{B} 20+\mathrm{N} 240$, respectively. The correlation coefficients between the gravimetric and TDR methods are also shown in Table 2.

As it can be seen, the correlation coefficients did not change after calibration of the TDR device. Considering the trend of correlation equations (Fig. 1), effect of applied N fertilizer in combination with biochar was observed in TDR measurements. The difference between the soil moisture measured by the TDR and the gravimetric methods was more pronounced with increasing dose of $\mathrm{N}$ fertilizer. When comparing the treatments without fertilization (BO + $\mathrm{NO}$ and $\mathrm{B} 20+\mathrm{N} 0$ ), no substantial differences between the TDR measurement and the gravimetric method were observed. Figs. 2 and 3 show the course of daily precipitation and volumetric water content measured by both gravimetric and TDR methods for non-fertilized and fertilized treatments. 
Table 2 Comparison of the TDR measured and calibrated values within $\pm 10 \%$ with gravimetric measurement and the obtained correlation coefficients

\begin{tabular}{|c|c|c|c|c|c|c|c|}
\hline & \multirow{2}{*}{$\begin{array}{c}\text { Total } \\
\text { number of } \\
\text { measurements }\end{array}$} & \multicolumn{2}{|c|}{$\begin{array}{l}\text { No. of measurements within } \\
\text { difference of } \pm 10 \%\end{array}$} & \multicolumn{2}{|c|}{$\begin{array}{l}\text { Percentage within difference } \\
\text { of } \pm 10 \%\end{array}$} & \multicolumn{2}{|c|}{ Correlation coefficient $\left(R^{2}\right)$} \\
\hline & & $\begin{array}{c}\text { measured } \\
\text { values (TDR) }\end{array}$ & $\begin{array}{l}\text { calibrated } \\
\text { values (TDR) }\end{array}$ & $\begin{array}{c}\text { measured } \\
\text { values (TDR) }\end{array}$ & $\begin{array}{l}\text { calibrated } \\
\text { values (TDR) }\end{array}$ & $\begin{array}{l}\text { measured } \\
\text { values (TDR) }\end{array}$ & $\begin{array}{c}\text { calibrated } \\
\text { values (TDR) }\end{array}$ \\
\hline $\mathrm{BO}+\mathrm{NO}$ & 42 & 28 & 34 & $66.67 \%$ & $80.95 \%$ & 0.93 & 0.93 \\
\hline $\mathrm{B2O}+\mathrm{NO}$ & 42 & 28 & 36 & $66.67 \%$ & $85.71 \%$ & 0.97 & 0.97 \\
\hline $\mathrm{B} 20+\mathrm{N} 160$ & 42 & 28 & 35 & $66.67 \%$ & $83.33 \%$ & 0.97 & 0.97 \\
\hline$B 20+N 240$ & 42 & 26 & 34 & $61.90 \%$ & $80.95 \%$ & 0.98 & 0.98 \\
\hline
\end{tabular}

According to the trend of volumetric water content for non-fertilized treatments (Fig. 2), the differences between the moisture measured by TDR device and gravimetric method were small ( 0 up to $3 \%$ vol.). Such a variability might be caused by TDR device measurement inaccuracy. Following the trend of the volumetric water content for fertilized treatments (Fig. 3), lower values (from 0 up to 5\% vol.) measured by TDR were observed in comparison to the gravimetric method. The greatest differences can be observed especially during the dry summer season (June September 2017) in case of both fertilized treatments. On the basis of the results, the differences between the gravimetric method and the TDR method were considerable. It is also interesting to note that there were observed not only higher correlation coefficients $\left(R^{2}\right)-0.97$ and 0.98 - for fertilized treatments (B20 + N160 and B20 + N240, respectively) but also even larger differences in volumetric water content in contrast to the values obtained by gravimetric method. In the case of the control variant $(\mathrm{BO}+\mathrm{N} 0)$, the correlation coefficient was the lowest $\left(R^{2}=0.93\right)$, however, the difference between the water content measured by both methods was negligible. Non-fertilized treatment $\mathrm{B} 20+\mathrm{N} 0$ resulted in small differences and a high correlation coefficient $\left(R^{2}=\right.$ 0.97). Using soil moisture values obtained by the CS659 sensor without prior calibration may lead to errors in the results. After applying the calibration equations obtained from the linear relationship between the gravimetric and TDR methods for the four experimental treatments, the accuracy of the measured TDR values throughout the vegetation period visibly improved, what can also be seen in Fig. 2 and Fig. 3. The soil water content values have been improved in all treatments to a range of 0 up to $2 \%$ vol. when compared to the gravimetric method. After the calibration, the values of volumetric water content measured by TDR are comparable with values determined by the gravimetric method.

Soil electrical conductivity, and thus also soil salinity, are affected by application of soil amendments such as fertilizers,

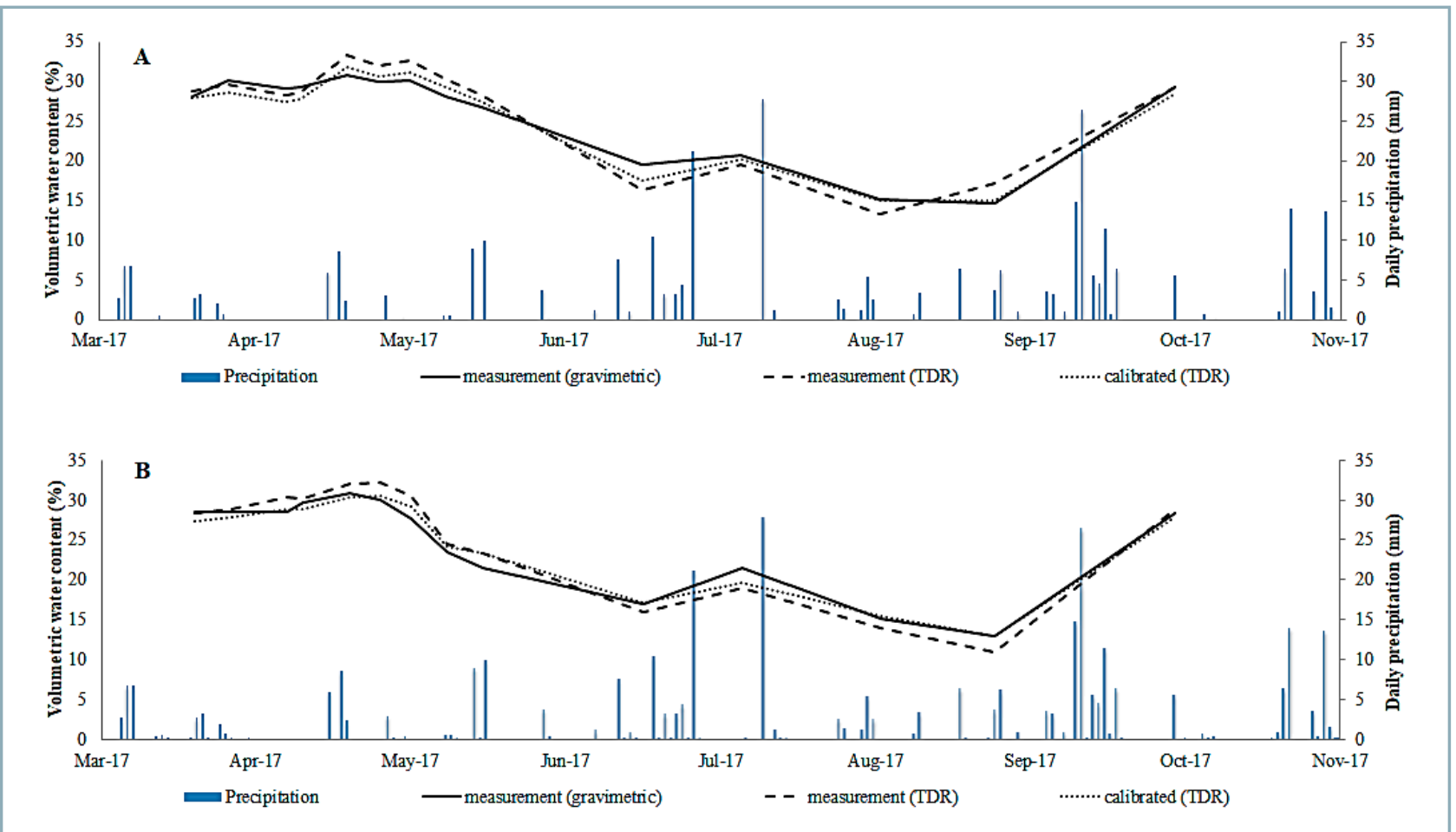

Fig. 2 Graphical trends of VWC measured by gravimetric and TDR methods and calibrated TDR values for non-fertilized treatments A) $\mathrm{BO}+\mathrm{NO}$ and B) $\mathrm{B} 20+\mathrm{NO}$ 

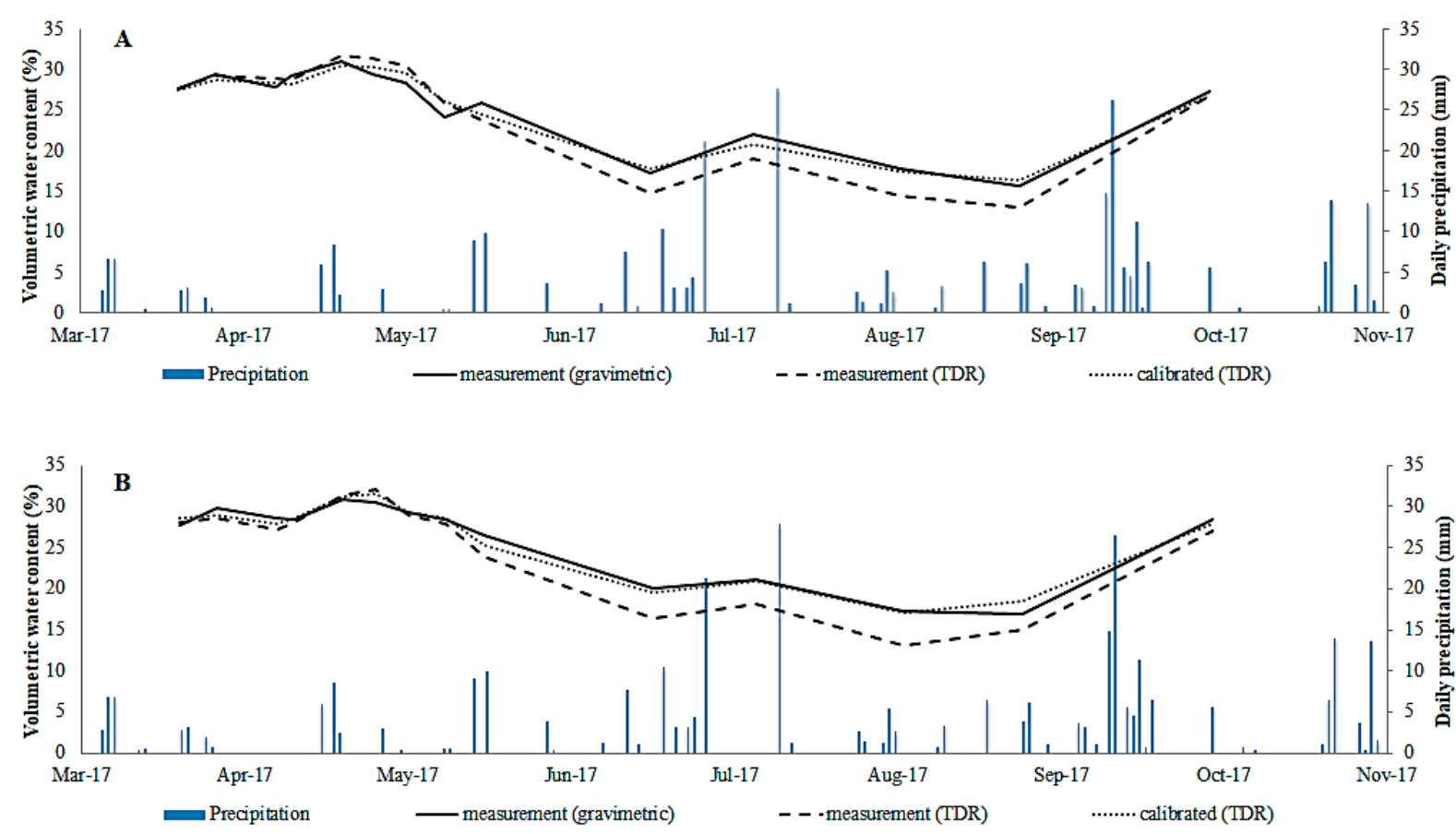

Fig. 3 Graphical trends of VWC measured by gravimetric and TDR methods and calibrated TDR values for fertilized treatments A) $\mathrm{B} 20+\mathrm{N} 160$ and B) $\mathrm{B} 20+\mathrm{N} 240$

manure and composts. Nitrogen fertilizer application can increase salinity and should be monitored closely on sites with potential salinity concerns. Salinity of soil solution can be increased significantly by addition of nitrogen, because nitrogen salts are generally quite soluble with little resultant effect on the solubility of other salts that may already be present in the soil solution. Therefore, dissolved nitrogen fertilizers are additional to the total salt in solution (Yaron, 1981). Several authors, including Jiangpei et al. (2015), have investigated the impact of $\mathrm{N}$ fertilizers on increasing soil salinity. In their particular study, nitrogen was applied at high doses of 600 and 1,200 $\mathrm{kg} \cdot \mathrm{ha}^{-1}$. The authors stated that salinity had increased significantly after $\mathrm{N}$ addition. The increase in soil salinity was attributed to the nitrification of excess N fertilizer. Similarly, Bryla et al. (2010) pointed out that increasing $\mathrm{N}$ application had effect on soil electrical conductivity. The application of granular $\mathrm{N}$ fertilizer may increase the electrical conductivity of the soil solution. One of the disadvantages of TDR devices is their inaccurate measurement in soils with higher salinity. There is a lack of information on the soil salinity or electrical conductivity at our experimental site, however, the results show that, in treatments with added nitrogen fertilizer at doses of 160 and $240 \mathrm{~kg} \cdot \mathrm{ha}^{-1}$, TDR measurements were performed with better inaccuracy in contrast to non-fertilized treatments. Using the information observed by Jiangpei et al. (2015) and Bryla et al. (2010), we assume that one of the reasons of differences in the obtained values might be due to the $\mathrm{N}$ fertilizer application.

\section{Conclusion}

The paper presents evaluation of the effect of applied $\mathrm{N}$ fertilizer at doses of 160 and $240 \mathrm{~kg} \cdot \mathrm{ha}^{-1}$ on the accuracy of soil moisture measurement with a HydroSense II device operating under the principle of TDR method. The measurements using TDR devices can result in errors when there is a high salt concentration in the soil. It is assumed that $\mathrm{N}$ fertilization increased salinity in the soil, which in turn led to measurement inaccuracies in fertilized treatments. Values on soil volumetric water content obtained by TDR for fertilized treatments (B20 + N160 and B20 + N240) differed by up to $5 \%$ vol. in comparison to gravimetric method. In case of non-fertilized treatments (B0 + N0 and B20 + N0), the differences were negligible. After application of calibration equations for each treatment, the differences in obtained values dropped to 0 up to $2 \%$ vol. during the whole crop vegetation period.

\section{Acknowledgement}

This study was financially supported by the projects APVV15-0160, KEGA 019SPU-4/2020, 026SPU-4/2020 and VEGA $1 / 0064 / 19,1 / 0747 / 20$.

\section{References}

ABBASPOUR-GILANDEH, Y. - HASANKHANI-GHAVAM, F. SHAHGOLI, G. - SHRABIAN, V. R. - ABBASPOUR-GILANDEH, M. 2018. Investigation of the effect of soil moisture content, contact surface material and soil texture on soil friction and soil adhesion coefficients. In Acta Technologica Agriculturae, vol. 21, no. 2, pp. 44-50.

ANTAL, J. - IGAZ, D. 2012. Applied Agrohydrology. Nitra : Slovak University of Agriculture in Nitra, 210 pp. ISBN 978-80-552-0731-5. (In Slovak: Aplikovaná agrohydrológia).

ANTAL, J. - BÁREK, V. - ČIMO, J. - HALAJ, P. - HALÁSZOVÁ, K. HORÁK, J. - IGAZ, D. - JURÍK, L.. - MUCHOVÁ, Z. - NOVOTNÁ, B. - 
ŠINKA, K. 2014. Hydrology of Agriculture Landscape. Nitra : Slovak University of Agriculture in Nitra, 371 pp. ISBN 978-80-552-1257-9. (In Slovak: Hydrológia polnohospodárskej krajiny).

BONNELL, R. B. - BROUGHTON, R. S. - ENRIGHT, P. 1991. The measurement of soil moisture and bulk soil salinity using time domain reflectometry. In Canadian Agricultural Engineering, vol. 33, no. 2, pp. 225-229.

BRYLA, D. R. - SHIREMAN, A. D. - MACHADO, R. M. A. 2010. Effects of method and level of nitrogen fertilizer application on soil $\mathrm{pH}$, electrical conductivity, and availability of ammonium and nitrate in blueberry. In Acta Horticulturae, vol. 868, pp. 95-102.

CHANDLER, D. G. - SEYFRIED, M. - MURDOCK, M. - MCNAMARA, J. 2014. Field calibration of water content reflectometers. In Soil Science, vol. 68, no. 5, pp. 1501-1507.

HOLZMAN, M. - RIVAS, R. - CARMONA, F. - NICLÒS, R. A. 2017. A method for soil moisture probes calibration and validation of satellite estimates. In MethodsX, vol. 4, pp. 243-249.

HOOK, W. R. - FERRÉ, T. P. A. - LIVINGSTON, N. J. 2004. The effects of salinity on the accuracy and uncertainty of water measurement. In Soil Science of America Journal, vol. 68, pp. 47-56.

HORÁK, J. - KONDRLOVÁ, E. - IGAZ, D. - ŠIMANSKÝ, V. - FELBER R. - LUKÁČ, M. - BALASHOV, E. V. - BUCHKINA, N. P. - RIŽIJA, E. JANKOWSKI, M. 2017. Biochar and biochar with $\mathrm{N}$-fertilizer affected soil $\mathrm{N}_{2} \mathrm{O}$ emission in Haplic Luvisol. In Biologia, vol 72, no. 9, pp. 995-1001.

IGAZ, D. - BÁREK, V. - HALAJ, P. - TAKÁČ, J. - ČIMO, J. 2008. A comparison of measured soil moisture with simulated results obtained by selected models for Danubian lowland. In Cereal Research Communication, vol. 36, pp. 1619-1622.

IGAZ, D. - ŠIMANSKÝ, V. - HORÁK, J. - KONDRLOVÁ, E. - DOMANOVÁ, J. - RODNÝ, M. - BUCHKINA, N. P. 2018. Can a single dose of biochar affect selected soil physical and chemical characteristics? In Journal of Hydrology and Hydromechanics, vol. 66, no. 4, pp. 421-428.

IUSS Working Group WRB. 2014. World reference base for soil resources 2014. Update 2015. International soil classification system for naming soils and creating legends for soil maps. World Soil Resources Reports No. 106, FAO, Rome.

JIANGPEI, H. - JIACHUN, S. - LINGZAO, Z. - JIANMING, X. LAOSHENG, W. 2015. Effects of nitrogen fertilization on the acidity and salinity of greenhouse soils. In Environmental Science and Pollution Research, vol. 22, no. 4, pp. 2976-2986.

JURIGA, M. - ŠIMANSKÝ, V. - HORÁK, J. - KONDRLOVÁ, E. - IGAZ, D. - POLLÁKOVÁ, N. - BUCHKINA, N. P. - BALASHOV, E. V. 2018. The effect of different rates of biochar and biochar in combination with $\mathrm{N}$ fertilizer on the parameters of soil organic matter and soil structure. In Journal of Ecological Engineering, vol. 19, no. 6, pp. 153-161.

KONDRLOVÁ, E. - HORÁK, J. - IGAZ, D. - DOBIÁŠOVÁ, D. 2017. The possibility of using digital images in assessment of plant canopy development and weed spread. In Acta Horticulturae et Regiotecturae, vol. 20, no. 2, pp. 35-39.

KONDRLOVÁ, E. - HORÁK, J. - IGAZ, D. 2018. Effect of biochar and nutrient amendment on vegetative growth of spring barley (Hordeum vulgare L. var Malz). In Australian Journal of Crop Science, vol. 12, no. 2, pp. 178-184.
LIMA, J. G. A. - OLIVEIRA, A. S. - SOUZA, L. S. - SILVA, N. D. - VIANA P. C. 2018. Calibration of a soil moisture sensor with disturbed and undisturbed soil samples from Bahia. In Revista Brasileira de Engenharia Agrícola e Ambiental, vol. 22, no. 10, pp. 696-701.

PRODUCT MANUAL HS2 and HSP2 (HydroSense II). 2019. ๑ 20112019. Available online: https://s.campbellsci.com/documents/au/ manuals/hs2.pdf

QUINONES, H. - NEMETH, I. 2003. Comparison of three calibration procedures for TDR soil moisture sensors. In Irrigation and Drainage, vol. 52, pp. 203-2017.

SHAIKH, J. - YAMSANI, S. K. - SEKHARAN, S. - RAKESH, R. R. 2019. Performance evaluation of 5TM sensor for real-time monitoring of volumetric water content in landfill cover system. In Civil Engineering Materials, vol. 8, no. 1, pp. 322-335.

SHUKLA, A. - PANCHAL, H. - MISHRA, M. - PATEL, P. R. - SRIVASTAVA, H. S. - PATEL, P. - SHUKLA, A. K. 2014. Soil moisture estimation using gravimetric technique and FDR probe technique: A comparative analysis. In American International Journal of Research in Formal Applied \& Natural Sciences, vol. 8, no. 1, pp. 89-92.

SMITH, K. A. - MULLINS, CH. E. 2001. Soil water content. In Soil Environmental Analysis, $2^{\text {nd }}$ ed. New York : Marcel Dekker, Inc., 637 pp. ISBN 0-8247-0414-2.

SUSHA, L. S. U. - SINGH, S. N. - BAGHINI, M. S. 2014. A critical review of soil moisture measurement. In Measurement, vol. 54, pp. 92-105. ŠIMANSKÝ, V. - HORÁK, J. - IGAZ, D. - BALASHOV, E. V. - JONCZAK, J. 2018. Biochar and biochar with $\mathrm{N}$ fertilizer as a potential tool for improving soil sorption of nutrients. In Journal of Soil Sediments, vol. 18, no. 4, pp. 1432-1440.

TANRIVERDI, C. - DEGIRMENCI, H. - GONEN, E. - BOYACI, S. 2016. A comparison of the gravimetric and TDR methods in terms of determining the soil water content of the corn plant. In Scientific Papers. Series A. Agronomy, vol. 59, pp. 153-158.

VITKOVÁ, J. - ŠURDA, P. - KONDRLOVÁ, E. - HORÁK, J. - RODNÝ, M. 2017. Analysis of soil water content and crop yield after biochar application in field conditions. In Plant Soil and Environment, vol. 63 , no. 12 , pp. $569-573$.

WYSEURE, G. C. L. - MOJID, M. A. - MALIK, M. A. 1997. Measurement of volumetric water content by TDR in saline soils. In European Journal of Soil Science, vol. 48, pp. 347-354.

YARON, D. 1981. Salinity in Irrigation and Water Resources. New York: Marcel Dekker, Inc., 448 pp. ISBN 0-8247-6741-1. 